\title{
ADAPTIVE RESPIRATORY RESPONSE OF RAT PANCREATIC ACINAR CELLS TO MITOCHONDRIAL MEMBRANE DEPOLARIZATION
}

\author{
B. O. MANKO ${ }^{\bowtie}$, O. O. BILONOHA, V. V. MANKO \\ Ivan Franko National University of Lviv, Ukraine; \\ 凶e-mail: bohdan.manko@Inu.edu.ua
}

Received: 06 December 2018; Accepted: 14 March 2019

\begin{abstract}
The dependence of uncoupled respiratory capacity of intact pancreatic acini on oxidative substrate supply and functional cell state has not yet been studied in detail. In this study, the respiratory responses of isolated pancreatic acini to FCCP were measured with Clark electrode and mitochondrial membrane potential was assessed with rhodamine123 fluorescence. The response of acini to FCCP was characterized with maximal uncoupled respiration rate, optimal FCCP concentration, respiration acceleration and deceleration. Maximal uncoupled respiration rate substantially increased upon the oxidation of glucose + glutamine (3.03 \pm 0.54 r.u.), glucose + glutamine + pyruvate $(2.82 \pm 0.51$ r.u.), glucose + isocitrate (2.71 \pm 0.33 r.u.), glucose + malate (2.75 \pm 0.38 r.u.), glucose + monomethyl-succinate ( $2.64 \pm 0.42$ r.u.) or glucose + dimethyl$\alpha$-ketoglutarate (2.36 \pm 0.33 r.u.) comparing to glucose alone (1.73-2.02 r.u.) or no substrate (1.76 \pm 0.33 r.u.). The optimal FCCP concentration was the highest $(1.75 \mu \mathrm{M})$ upon glucose + glutamine + pyruvate combination and the lowest $(0.5 \mu M)$ upon glutamate, combinations of glucose with isocitrate, malate, succinate or $\alpha$-ketoglutarate. Respiration acceleration after FCCP application was the highest with dimethyl- $\alpha$ ketoglutarate. Following the peak respiration, time-dependent deceleration was observed. It increased with FCCP concentration and depended on oxidative substrate type. Deceleration was the highest upon malate or isocitrate oxidation but was not observed in case of glutamine or dimethyl- $\alpha$-ketoglutarate oxidation. Pyruvate alone or in combination with glutamine and glucose significantly decreased the depolarizing effect of FCCP on mitochondrial membrane potential and increased respiration elasticity coefficient with respect to the membrane potential change. Thus, in pancreatic acinar cells, the combination of pyruvate, glutamine and glucose enables the optimal adaptive respiratory response to membrane depolarization.
\end{abstract}

Keywords: pancreatic acinus, oxygen consumption, mitochondria, depolarization, respiratory uncouplers, oxidative substrates.

$\mathrm{M}$ itochondrial respiratory capacity and membrane potential are useful indicators of cell state. The uncoupled respiratory capacity of pancreatic acinar cells is markedly reduced by in vitro anoxia [1] and in experimental pancreatitis models in vivo [2]. In addition, mitochondrial membrane depolarization in pancreatic acinar cells may be caused by a range of pathological factors, such as ethanol [3], fatty acid ethyl esters [4], bile acids [5, 6], $\mathrm{H}_{2} \mathrm{O}_{2}$ [7] and others. Furthermore, mitochondrial membrane potential dissipated in cerulein-induced experimental pancreatitis model
[8]. However, the mitochondrial membrane depolarization does not necessarily indicate a pathological process. For example, physiological stimulation of pancreatic acinar cells with secretagogues causes mitochondrial depolarization [5] as well as increased ATP synthesis [9] and uncoupled respiration rate [10]. The capacity of the cells to adequately respond to mitochondrial depolarization thus may determine the course of physiological or pathological processes.

Protonophores, such as CCCP or FCCP, are useful tools to assess the capacity of mitochondria to respond to depolarization. In pancreatic acinar

(C) 2019 Manko B. O. et al. This is an open-access article distributed under the terms of the Creative Commons Attribution License, which permits unrestricted use, distribution, and reproduction in any medium, provided the original author and source are credited. 
live cells studies, the use of these respiratory uncouplers is not standardized to date. In respiration studies, the protonophore is usually carefully titrated over the range of concentrations to reach its maximal effect on respiration and thus assess the respiratory capacity of mitochondria $[1,10]$. However, in other types of experiments, often only a single dose of protonophore is used to depolarize mitochondria, without taking into the account the effect on respiration $[6,11]$.

The respiratory responses to protonophore depend on oxidative substrate type (glucose, pyruvate, amino acids) not only in isolated mitochondria, but also when plasma membrane integrity is preserved in, e.g. synaptosomes [12], cardiomyocytes [13] or pancreatic islets [14]. The dependence of uncoupled respiration on oxidative substrates supply was not systematically studied in intact pancreatic acini. The differences in oxidative substrates supply is an apparent reason for the discrepancy in reported maximal rates of protonophore-stimulated respiration of rat pancreatic acinar cells: FCCP had a much lower effect on respiration when only glucose was present [10] than in case of glutamine supplementation [1]. Pyruvate and glucose were used to study mitochondrial ATP synthesis in pancreatic acinar cells [9], but not in respiration studies.

It is well known that in live cells protonophores can cause both respiration stimulation and inhibition [15]. Strong and prolonged depolarization with protonophore, leading to initial respiration burst and gradual respiratory capacity loss, serve both as an experimental model of mitochondrial dysfunction and a diagnostic tool in assessing mitochondrial adaptation capacity. Thus, the detailed study of the capacity of mitochondria in live cells to respond to protonophore with changes in respiration and membrane potential is useful for better understanding of mitochondrial metabolism, disease pathogenesis and may aid the discovery of the new therapeutic approaches.

The goal of this study was to systematically study the respiratory responses of intact pancreatic acini to mitochondrial membrane depolarization with uncoupler FCCP.

\section{Materials and Methods}

Reagents used in all experiments were purchased from Sigma-Aldrich (sodium chloride S7653, glucose G8270, N-2-hydroxyethylpiperazine-N'- 2-ethanesulfonic acid (HEPES) H3375, soybean trypsin inhibitor T9128, bovine serum albumin (BSA) A6003, succinate S3674, L-malate 112577, sodium pyruvate $\mathrm{P} 2256$, glutamic acid 49449, monomethyl-succinate M81101, D-methyl-2-oxoglutarate 349631, $\alpha$-ketoglutaric acid K1875, carbonyl cyanide-4-(trifluoromethoxy) phenylhydrazone (FCCP) C2920, oligomycin O4876, collagenase type IV C5138, rhodamine 123 R8004 and Merck Chemicals (Calcium chloride dihydrate, 1725701000). All other reagents were of purest available grade.

All manipulations with animals have been performed in accordance with the EU Directive 2010/63/ $\mathrm{EU}$ for animal experiments and relevant laws of Ukraine. Experimental protocols were approved by the Animal Care and Use Committee of Ivan Franko National University of Lviv. Experiments were carried out on wild type white male rats (250-300 g). Animals were kept under the standard conditions of vivarium at room temperature $\left(18-20^{\circ} \mathrm{C}\right)$ and on a basic diet.

A suspension of isolated pancreatic acini was obtained following collagenase treatment (Sigma, type IV, $0.2 \mathrm{mg} / \mathrm{ml}$ ) according to the previously reported method [16]. Cell viability, evaluated with the trypan blue $(0.1 \%)$ test, was $>93 \%$. Cell counting was performed using haemocytometer.

The rate of oxygen consumption was measured with Clark oxygen electrode (Biological oxygen monitor YSI 5300, Yellow Springs Instrument, USA) in the closed 1.6-mL glass respiration chamber at $37^{\circ} \mathrm{C}$. Before respiration measurement, suspension of pancreatic acini was pre-incubated (15 min, $37^{\circ} \mathrm{C}$ ) in medium with oxidative substrates of choice (see Incubation media section). Protonophore FCCP $(0.5,1,1.5$ and $2 \mu \mathrm{M})$ was used to stimulate the respiration. Oligomycin $(5 \mu \mathrm{M})$ was added to inhibit ATP-synthase.

Mitochondrial membrane potential level was assessed by semi-quantitative method using rhodamine123 staining in dequench mode [5]. Fluorescence was measured with fluorescent microscope LUMAM-I-1 at excitation wavelength of $505 \pm 25 \mathrm{~nm}$ (green LED) and emission wavelength 600-700 nm. Signal was recorded with DSLR Nikon D3000 camera (CCD Sensor, 10 million pixels). Photographs were stored in NEF format, mean cell fluorescence intensity was calculated using ImageJ. The macros used could distinguish cells from the background by the fluorescence intensity. 
Samples of acini $(0.5 \mathrm{ml})$ were incubated for $15 \mathrm{~min}$ at $37^{\circ} \mathrm{C}$ in the media with substrates of interest and rhodamine123 $(10 \mu \mathrm{g} / \mathrm{ml})$. After Rhodamine 123 washout, a series of aliquots were taken for incubation with FCCP $\left(0.5-5 \mu \mathrm{M}, 1 \mathrm{~min}, 37^{\circ} \mathrm{C}\right)$. The bulk of cells were stored at room temperature in medium with substrate of interest. The fluorescence was quickly measured (during $1.5 \mathrm{~min}$ ) by taking photographs of at least 10 different acini.

Acini were obtained and stored in extracellular solution containing (mM): $140.0 \mathrm{NaCl}, 4.7 \mathrm{KCl}$, $1.3 \mathrm{CaCl}_{2}, 1.0 \mathrm{MgCl}_{2}, 10.0$ HEPES, 10.0 glucose, 2.0 glutamine, 2.0 sodium pyruvate, $0.01 \%$ (wt/vol) soybean trypsin inhibitor, $0.25 \%$ (wt/vol) BSA and MEM amino acid supplement; pH 7.4.

Basic incubation solution contained $(\mathrm{mM})$ : $140.0 \mathrm{NaCl}, 4.7 \mathrm{KCl}, 1.3 \mathrm{CaCl}_{2}, 1.0 \mathrm{MgCl}_{2}, 10.0$ HEPES, $0.01 \%$ (wt/vol) soybean trypsin inhibitor and $0.25 \%(\mathrm{wt} / \mathrm{vol}) \mathrm{BSA}$; pH 7.4. Solution was supplemented with one or several oxidative substrates: $10 \mathrm{mM}$ glucose or $2 \mathrm{mM}$ sodium pyruvate, isocitrate, glutamine, glutamate, $\alpha$-ketoglutarate, succinate, malate or membrane-permeant esters dimethyl$\alpha$-ketoglutarate and monomethyl-succinate.

Each experiment was performed with at least five separate preparations of isolated cells obtained from different animals (' $n$ ' always represents the number of animals). For mitochondrial membrane potential calculation, at least 10 different acini from each preparation were measured for each experimental group. The significance of difference between two groups was determined with a paired $t$-test. In the case of multiple comparisons, the Holm-Bonferroni test was additionally used.

\section{Results and Discussion}

Pyruvate and glutamine enhance FCCPstimulated respiration rate of pancreatic acini. To assess the effects of oxidative substrates on FCCPstimulated respiration, the extracellular solution was supplemented with glucose, pyruvate, glutamine or glutamate and isolated pancreatic acini were incubated for $15 \mathrm{~min}$ at $37^{\circ} \mathrm{C}$. Acini were transferred to the respiratory cell; basal and FCCP-stimulated respiration was recorded. FCCP was added in a stepwise manner (final concentrations - 0.5, 1.0, 1.5 and $2.0 \mu \mathrm{M}$ ) with $\sim 2$ min interval between each addition.

Basal respiration rate did not depend on the oxidative substrate (Fig. 1, $B-D$ ). The lowest FCCP concentration $(0.5 \mu \mathrm{M})$ stimulated the respiration to $1.76 \pm 0.33$ r.u. when no substrates were pre- sent in the medium (control), and to a greater extent $(2.17 \pm 0.33 \mathrm{r.u})$, when glutamate was oxidized (Fig. 1, C). $1 \mu \mathrm{M}$ of FCCP further stimulated respiration upon pyruvate (Fig. 1, B) or glutamine (Fig. 1, $C$ ) oxidation but suppressed respiration in control or upon glutamate oxidation. FCCP at higher concentrations (1.5 and $2.0 \mu \mathrm{M})$ caused a decline of the respiration rate in all cases. Glutamine availability resulted in a significantly higher respiration rate after FCCP additions (1.0-2.0 $\mu \mathrm{M})$.

Thus, FCCP-stimulated respiration rate depends on oxidative substrate: pyruvate and glutamine support the high respiratory activity of mitochondria upon high protonophore loads, unlike of glucose or glutamate. The next experiments were carried out in the presence of glucose (control) to support glycolytic ATP synthesis under the condition of oxidative phosphorylation deficit (high FCCP loads) and assess the effects of substrate combinations on mitochondrial functional activity.

When glucose was present in the medium, FCCP $(0.5 \mu \mathrm{M})$ stimulated respiration to $1.83 \pm 0.30$ r.u., similarly to the combinations with glutamine and/or pyruvate (Fig. 1, D). After $1 \mu \mathrm{M}$ of FCCP was added, the respiration rate was higher upon glucose+glutamine and glucose+glutamine+pyruvate oxidation $(P=0.04$ and 0.03 , respectively, significance not confirmed with Holm-Bonferroni test). The highest respiratory rates were achieved after 1.5-2.0 $\mu \mathrm{M}$ FCCP when glutamine and glucose were oxidized irrespectively of pyruvate supplementation.

Thus, the effects of glucose and glutamine on FCCP-stimulated respiration are additive, unlike of glucose and pyruvate. Combination of all three substrates provides mitochondria the ability to respond with the highest respiration rates to high protonophore loads.

Krebs cycle intermediated and their methyl esters differently affect FCCP-stimulated respiration. In the next experiment, we evaluated the effects of Krebs cycle substrates (malate, isocitrate, succinate and $\alpha$-ketoglutarate) on FCCP-stimulated respiration of pancreatic acini. Basal respiration rate did not change significantly upon supplementation with these substrates. However, when malate or isocitrate was added to the glucose-rich medium, FCCP $(0.5 \mu \mathrm{M})$ increased respiration to higher levels than in control (glucose, Fig. 2, B). Higher FCCP concentrations inhibited respiration even stronger than in control. Succinate or $\alpha$-ketoglutarate did not increase 

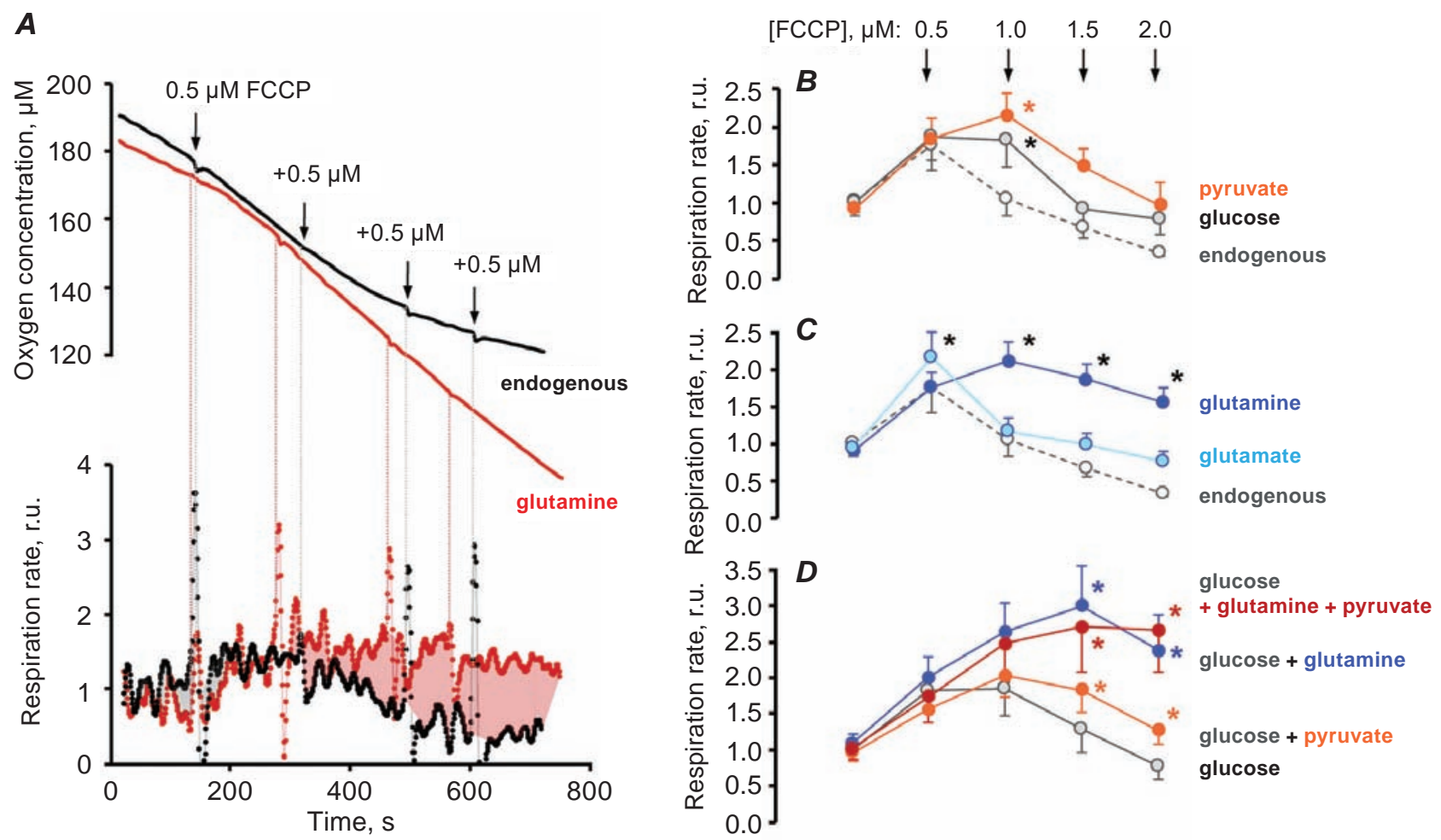

Fig. 1. Protonophore-stimulated respiration of pancreatic acini depends on oxidative substrate: $\boldsymbol{A}$ - original recordings of oxygen consumption by suspension of acini (top) and derived rate of respiration (bottom) upon endogenous substrates or glutamine $(2 \mathrm{mM})$ oxidation, FCCP was added to reach the final concentrations $0.5,1,1.5$ and $2 \mu \mathrm{M}$, in the bottom the difference between respiration rate in two experiments was marked grey (higher for endogenous substrates) or red (higher for glutamine); $\boldsymbol{B}-\boldsymbol{D}$ - the dependence of respiration on FCCP concentration and oxidative substrate (glucose - $10 \mathrm{mM}$, glutamine and pyruvate $-2 \mathrm{mM}$ ), data normalized to basal respiration (no FCCP) upon exogenous substrates $(\boldsymbol{B}, \boldsymbol{C})$ or glucose (D) oxidation; *significantly different to endogenous substrates $(\boldsymbol{B}$ and $\boldsymbol{C}$ ) or glucose $(\boldsymbol{D}), P<0.05 ; n=5$ (B and $\boldsymbol{C}$ ) or 6 (D); mean \pm SEM; r.u. - relative units, hereafter, r.u.

FCCP-uncoupled respiration, on the contrary - oxygen consumption was lower upon $1 \mu \mathrm{M}$ FCCP than in control (glucose, Fig. 2, C).

Whether the Krebs cycle substrates could be transported across the plasma membrane of pancreatic acinar cells are still unknown. To facilitate substrate permeation, we also used methyl esters monomethyl succinate and dimethyl- $\alpha$-ketoglutarate. Unlike natural substrates, ester forms significantly increased the uncoupled respiration (Fig. 2, D).

Maximal respiration rate and optimal FCCP concentration. To assess the functional capacity of pancreatic acinar cell's mitochondria upon maximal loads, we used two parameters: the maximal rate of uncoupled respiration and optimal FCCP concentration (concentration upon which the maximal respiration was achieved, the mean of all experiments in one condition). Often the optimal concentration was not uniform for each experiment.
Under control conditions (no substrate in solution) the maximal respiration rate and the optimal protonophore concentration were the lowest compared to other experiments (Table). Addition of different oxidative substrates resulted either in a sole increase of the maximal respiration rate (glutamate, isocitrate, malate, succinate, $\alpha$-ketoglutarate), or both rate and optimal concentration (glucose, pyruvate, glutamine, methyl-succinate, dimethyl- $\alpha$ ketoglutarate or their combinations). Both parameters of mitochondrial functional capacity were the highest when the combination of glucose, pyruvate and glutamine was utilized.

Three phases of uncoupled respiration. The optimal FCCP concentration markedly depended on the oxidative substrate and was largely influenced by respiration suppression at high FCCP doses. After more careful analysis it becomes evident that respiration decline is not an immediate consequence of 

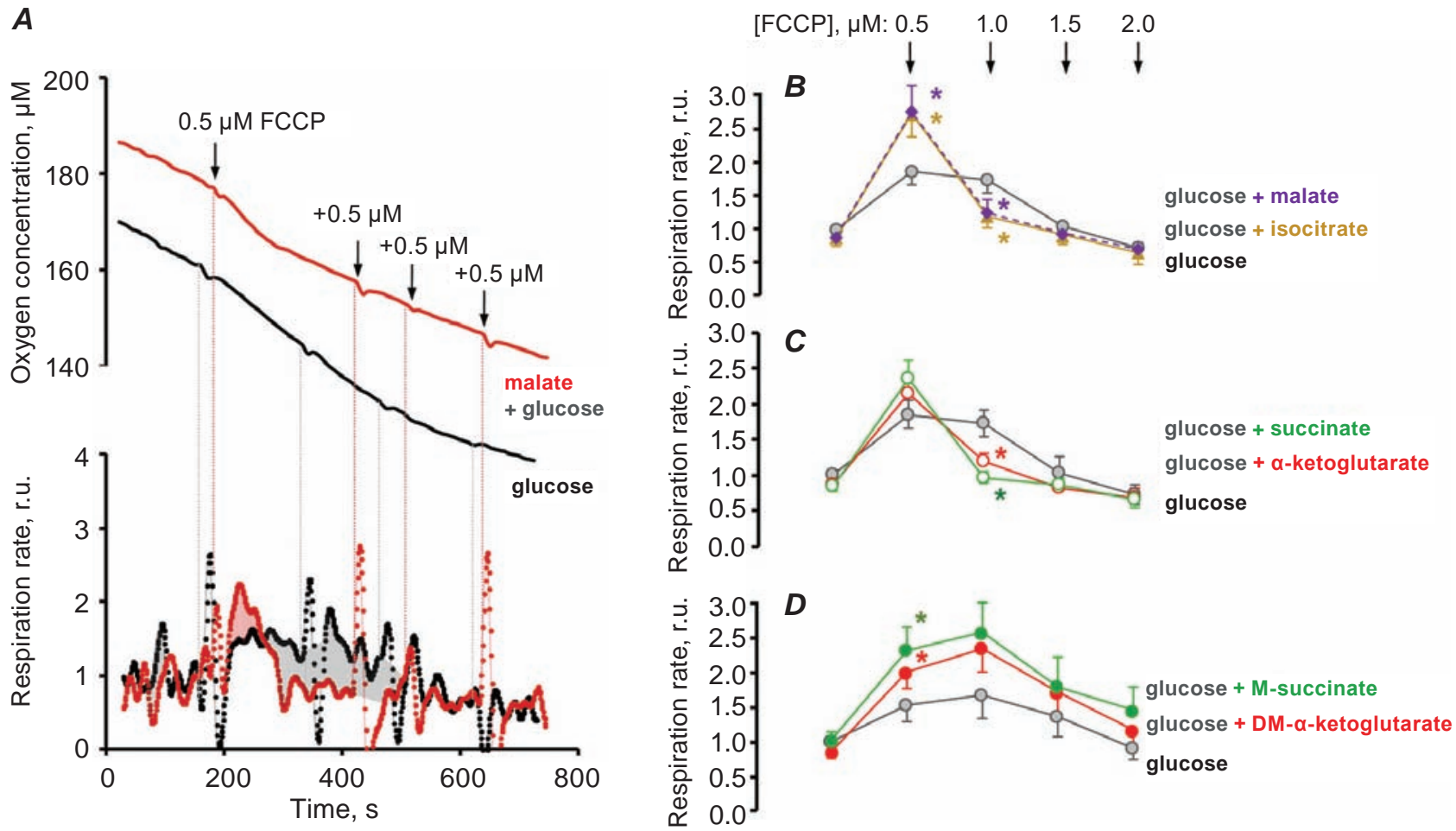

Fig. 2. Esters of TCA cycle substrates steadily enhance FCCP-stimulated respiration of pancreatic acini, in contrast to the natural substrates: $\boldsymbol{A}$ - original recordings of oxygen consumption by suspension of acini (top) and derived rate of respiration (bottom) upon glucose $(10 \mathrm{mM})$ or glucose + malate $(2 \mathrm{mM})$ oxidation, in the bottom the difference between respiration rate in two experiments was marked grey (higher for glucose) or red (higher for glucose + malate); $\boldsymbol{B}, \boldsymbol{C}$ - the dependence of respiration on FCCP concentration and oxidative substrates (glucose $-10 \mathrm{mM}$, isocitrate, malate, succinate and $\alpha$-ketoglutarate $-2 \mathrm{mM}$ ); $\mathbf{D}-F C C P$-stimulated respiration in the presence of substrate esters monomethyl-succinate ( $M$-succinate, $2 \mathrm{mM}$ ) or dimethyl- $\alpha$ ketoglutarate (DM- $\alpha$-ketoglutarate, $2 \mathrm{mM}$ ); data normalized to basal respiration (no FCCP) upon glucose oxidation; * significantly different to glucose, $P<0.05 ; n=8$ (B and $\boldsymbol{C})$ or 6 (D); mean \pm SEM

higher than optimal FCCP concentration application, rather it develops with time. The respiration rate steadily decreased after initial stimulation with $0.5 \mu \mathrm{M}$ FCCP (glucose + malate oxidation, Fig. 2, A). In this case, the following additions of higher FCCP concentrations did not reduce respiration.

Thus, we assumed that at least two factors determine the uncoupler-induced respiration change: uncoupler concentration and time. To discern these factors, in the following series of experiments FCCP was added only once at 0.5 or $1.5 \mu \mathrm{M}$.

After FCCP addition, three phases of respiration could be observed (Fig. 3, A):

1) increase in respiration rate (acceleration phase);

2) peak of respiration rate (maximal respiration phase);

3) decrease in respiration rate (deceleration
The changes in respiration rate in phases 1 and 3 are adequately described by a linear function. Thus, coefficients of acceleration $(a)$ or deceleration $(d)$ of the equations: $v(t)=v_{0}+$ at or $v(t)=v_{0}+d t$, were calculated with linear regression. For convenience, we used absolute values of $a$ and $d$.

It was found that acceleration of respiration depends both on FCCP concentration and oxidative substrate type. In most cases (except for glutamine oxidation) the acceleration was much higher after $1.5 \mu \mathrm{M}$ FCCP than after $0.5 \mu \mathrm{M}$. The acceleration caused by $1.5 \mu \mathrm{M}$ FCCP at glutamine oxidation was slower when compared to glucose (Fig. 3). Conversely, it was significantly higher upon malate or dimethyl- $\alpha$-ketoglutarate oxidation.

For most substrates (except for glutamine), the lowest FCCP concentration tested $(0.5 \mu \mathrm{M})$ already caused close to maximal peak respiration. In case of phase). 
Optimal FCCP concentration and maximal respiration rate

\begin{tabular}{lccc}
\hline \multicolumn{1}{c}{ Experimental conditions } & Optimal [FCCP], $\mu \mathrm{M}$ & $\begin{array}{c}\text { Maximal respiration } \\
\text { rate, r.u. }\end{array}$ & $n$ \\
\hline No substrate (control) & $\leq 0.5$ & $1.76 \pm 0.33$ & 5 \\
Glucose & $0.8 \pm 0.1$ & $1.91 \pm 0.33$ & \\
Pyruvate & $0.9 \pm 0.1$ & $2.12 \pm 0.21^{*}$ & \\
Glutamate & $\leq 0.5$ & $2.17 \pm 0.33^{*}$ & \\
Glutamine & $1.0 \pm 0.0$ & $2.12 \pm 0.26^{*}$ & 6 \\
\hline Glucose (control) & $0.8 \pm 0.1$ & $2.02 \pm 0.35$ & \\
+ Pyruvate & $1.1 \pm 0.1$ & $2.03 \pm 0.29$ & \\
+ Glutamine & $1.4 \pm 0.1$ & $3.03 \pm 0.54^{*}$ & \\
+ Pyruvate + Glutamine & $1.8 \pm 0.1$ & $2.82 \pm 0.51^{*}$ & \\
\hline Glucose (control) & $0.8 \pm 0.1$ & $1.91 \pm 0.20$ & \\
+ Isocitrate & $\leq 0.5$ & $2.71 \pm 0.33^{*}$ & \\
+ Malate & $\leq 0.5$ & $2.75 \pm 0.38^{*}$ & \\
+ $\alpha$-ketoglutarate & $\leq 0.5$ & $2.14 \pm 0.22$ & \\
+ Succinate & $\leq 0.5$ & $2.35 \pm 0.25$ & \\
\hline Glucose (control) & $0.9 \pm 0.1$ & $1.73 \pm 0.29$ & \\
+ Dimethyl- $\alpha$-ketoglutarate & $1.0 \pm 0.0$ & $2.36 \pm 0.33^{*}$ & \\
+ + Monomethyl-succinate & $0.8 \pm 0.1$ & $2.64 \pm 0.42^{*}$ & \\
\hline
\end{tabular}

Data always normalized to the basal respiration rate upon glucose oxidation; $n$ - number of animals; * $P<0.05$ comparing to the control (first row of each experiment); mean \pm SEM

glutamine oxidation, $1.5 \mu \mathrm{M}$ FCCP was required to reach the maximum respiration rate (Fig. $3, D$ ).

Deceleration of the uncoupled respiration (phase 3) was strongly substrate-dependent and usually increased with FCCP concentration (Fig. 3, $B-E$ ). Basal respiration also did decline slightly with time, for a similar extent in all experiments with substrates. This apparent artefact might be caused by oxygen diffusion into the respiration chamber or/ and a steady decline in cell viability. When $0.5 \mu \mathrm{M}$ FCCP was added, in most cases deceleration was comparable to the basal values. Only when malate or isocitrate was present, deceleration was significantly higher - compared both to basal and to the experiment with glucose oxidation $(P<0.05$; Fig. 3 , $B, C)$. When $1.5 \mu \mathrm{M}$ FCCP was added, deceleration was significantly higher compared to experiments with 0.5 FCCP in cases of glucose, pyruvate, succinate or malate oxidation $(P<0.05)$, but remained at the same level in cases of glutamine, dimethyl$\alpha$-ketoglutarate or isocitrate oxidation. In this experiment, deceleration was significantly lower upon glutamine or dimethyl- $\alpha$-ketoglutarate oxidation and higher upon malate or isocitrate oxidation when comparing to glucose $(P<0.05$; Fig. 3, $D, E)$. These data explain very well the previously established values of the optimal FCCP concentrations.

Glutamine and pyruvate reduce FCCP-induced mitochondrial potential dissipation. The respiration rate is limited by multiple factors, including mitochondrial membrane potential. Protonophores depolarize the mitochondrial membrane and abolish feed-back control of respiration. We assumed that the substrate-specific differences in respiration responses to protonophore are linked to the differences in FCCP-induced mitochondrial membrane depolarization decrease.

The fluorescence of rhodamine 123 in resting cells and was low and did not depend on the substrate (data not shown). After 1 min of incubation with FCCP, the fluorescence was relatively stable over 1.5 min (data not shown). It increased proportionally to FCCP concentration and at $2 \mu \mathrm{M}$ FCCP reached $\sim 80-120 \%$ of values at $5 \mu \mathrm{M}$ FCCP (Fig. 4, A, B). This was interpreted as a complete membrane potential dissipation. Matrix surface of 


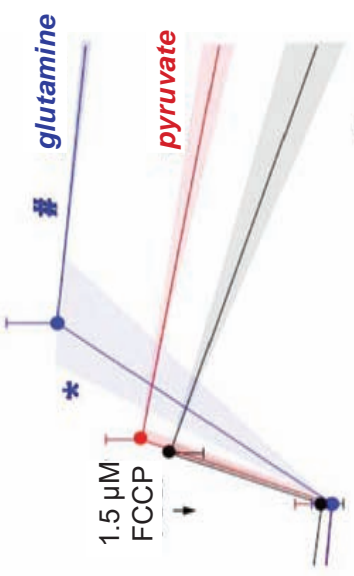

0

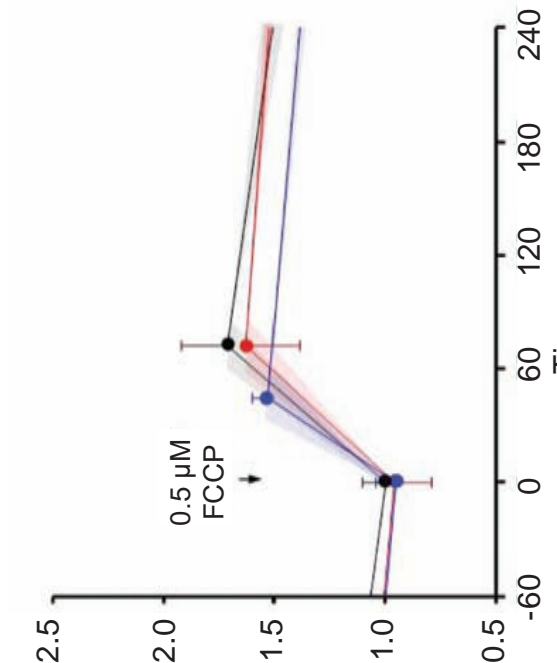

$\infty$

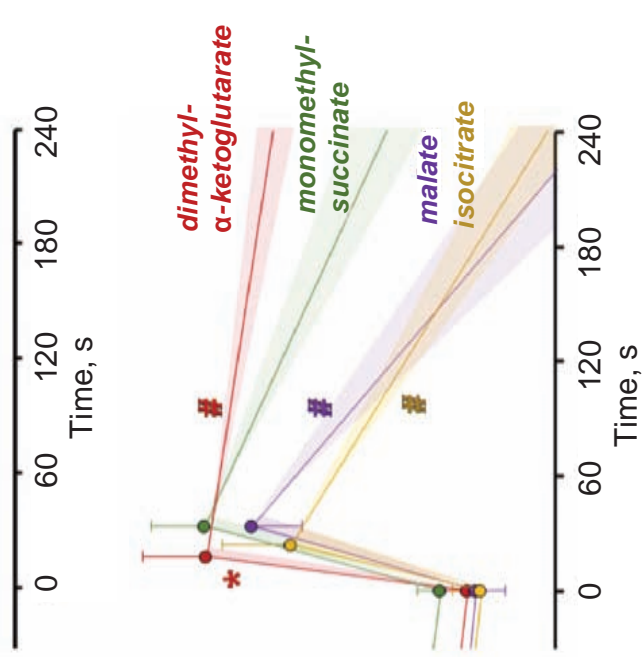

山

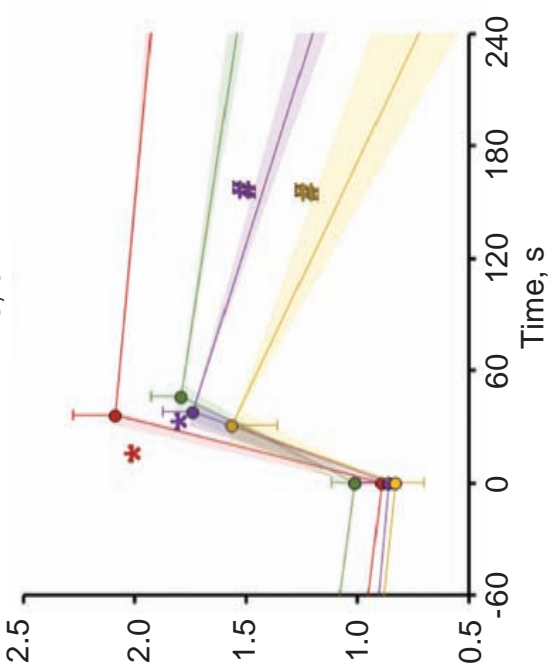

u

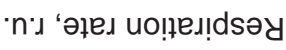

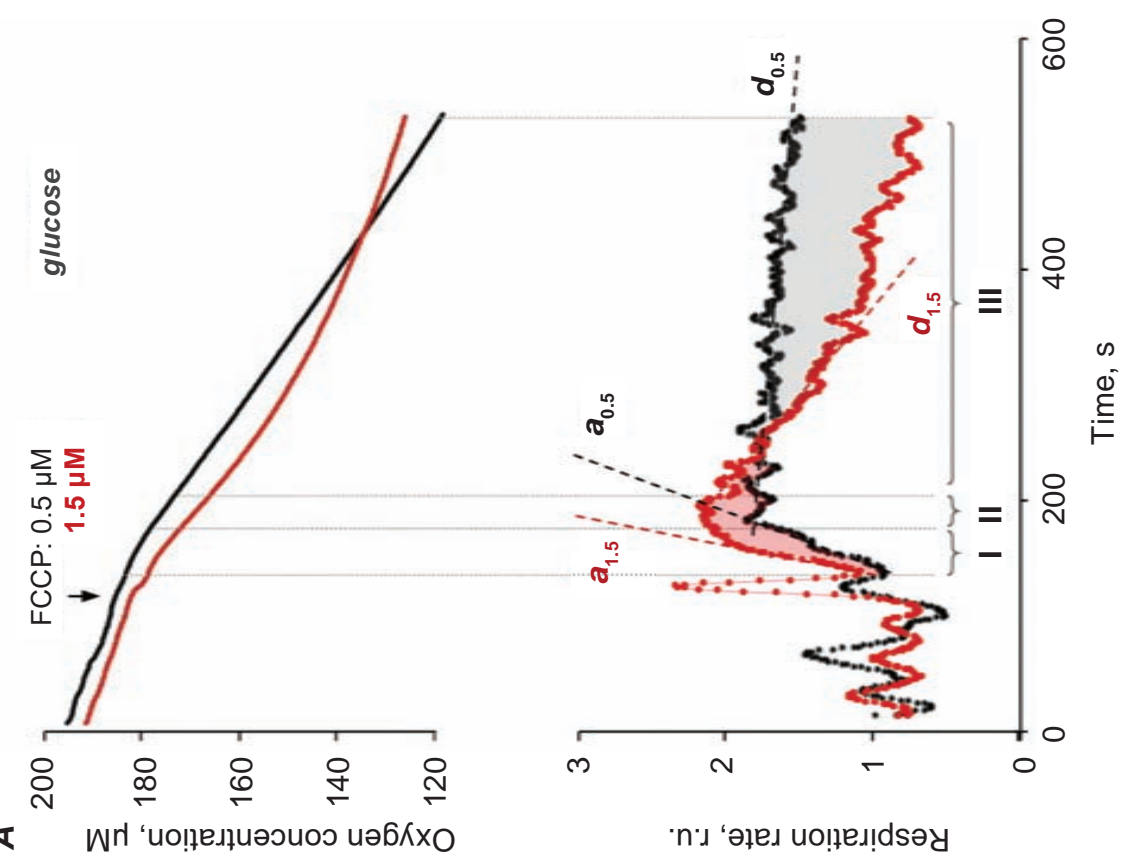

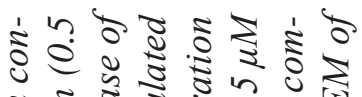
ป.

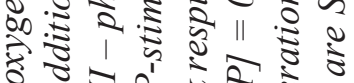
ป

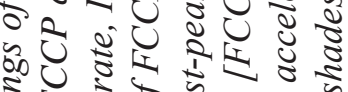
. 年 ช

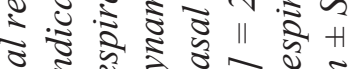

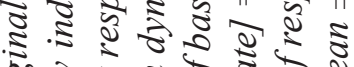
क人

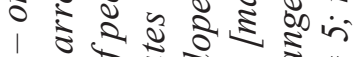
$<$ ₹

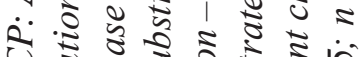
บ

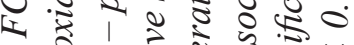

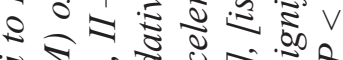

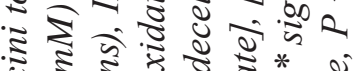

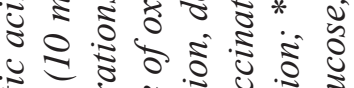

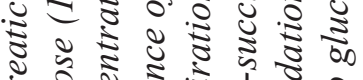
¿

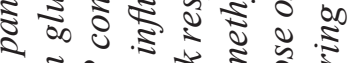

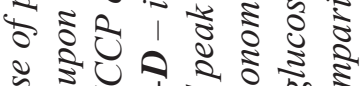
कृ ปิ

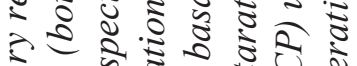

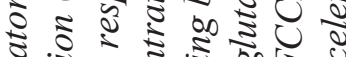
.

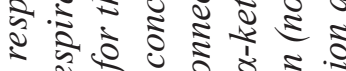

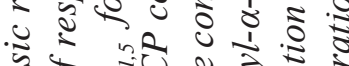
ปू .ई

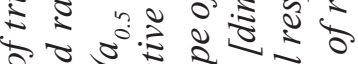

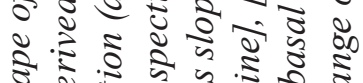

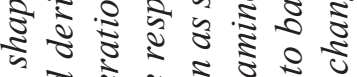

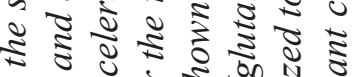
‡ ₹

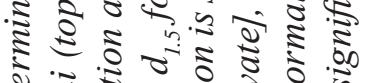

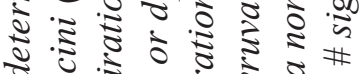
吾 0 吾

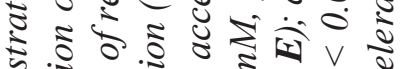
क ¿ की

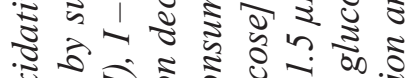
๑ิ

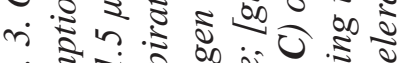

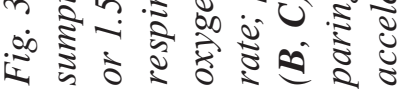


the mitochondrial membrane has a negative charge. FCCP causes the decrease of the absolute value of this charge, i.e. the inner mitochondrial membrane becomes depolarized. The maximal fluorescence intensity (at 2 or $5 \mu \mathrm{M}$ FCCP) was $\sim 2$-fold higher than basal and did not depend on oxidative substrate. Thus, we have normalized the data by taking basal fluorescence level as maximal membrane potential (1 r.u.) and maximal fluorescence - as zero membrane potential (0 r.u.).

An FCCP-induced decrease of mitochondrial membrane potential markedly depended on oxidative substrate. The membrane potential after incubation with 0.5 or $1 \mu \mathrm{M}$ FCCP was significantly higher when glutamine, pyruvate and glucose were present comparing to glucose only (Fig. 4, C). When pyruvate was present alone, 0.5 FCCP caused significantly less membrane potential drop comparing to glucose experiment (Fig. 4, D). Conversely, upon monomethyl-succinate oxidation, FCCP caused significantly stronger dissipation of membrane potential (Fig. 4, F). Glutamine, when compared to glucose, did not cause any significant changes in membrane potential response to FCCP (Fig. 4, E). As expected, the increase in the respiration rate was proportional to the decrease in membrane potential, but the extent of $\Psi$ respiration stimulation depended on the substrate (Fig. 4, $C-F$ ).

To evaluate the degree of respiration rate dependence on the mitochondrial membrane potential, the elasticity coefficients were calculated for the initial changes upon $0.5 \mu \mathrm{M}$ FCCP according to the equation:

$$
\varepsilon=\frac{d v}{v} \cdot \frac{\Delta \psi_{\mathrm{m}}}{d\left(\Delta \psi_{\mathrm{m}}\right)},
$$

where $v$ - rate of oligomycin-insensitive respiration, $\Delta \Psi_{\mathrm{m}}$ - maximal mitochondrial membrane potential without FCCP; differentials calculated after adding $0.5 \mu \mathrm{M}$ FCCP.

Elasticity coefficient was the highest when the combination of glucose, glutamine and pyruvate was present (-42.1) and the lowest when monomethylsuccinate was oxidized (-2.6, Fig. 4).

In this study, we have described the adaptive respiratory responses of isolated rat pancreatic acini to mitochondrial depolarization with protonophore. The typical response to single FCCP dose is characterized with respiration acceleration, peak respiration rate, and deceleration. After titration with several FCCP concentrations, it is possible to de- rive two other parameters - the maximal uncoupled respiration and optimal protonophore concentration (a concentration causing the maximal respiratory response). In addition, when combined with semiquantitative mitochondrial membrane potential measurement, it was possible to derive elasticity coefficients for respiration rate. All these parameters were highly sensitive to oxidative substrate type. The usefulness of the new described parameters in assessing mitochondrial function or dysfunction in live cells has yet to be tested in various experimental conditions and disease models.

The acceleration of respiration is potentially a measure of how rapidly mitochondrial oxidative systems can accommodate to depolarization, and it depends both on depolarization extent and substrate. In pancreatic acini, the respiration acceleration was the fastest upon dimethyl- $\alpha$-ketoglutarate oxidation, and the slowest upon glutamine. This is logical, as two additional enzymes, glutaminase and glutamate dehydrogenase, are involved in glutamine catabolism.

At the end of the acceleration phase, the respiratory peak or plateau could be defined. The respiratory plateau is registered when no significant timedependent respiration deceleration is developed. In pancreatic acinar cells, glutamine and dimethyl$\alpha$-ketoglutarate are the only substrates capable of supporting the stationary respiratory states upon high FCCP concentration $(1.5 \mu \mathrm{M})$. This, however, does not necessarily mean that in various cases of prolonged depolarization, caused by physiological or pathological factors, mitochondria of pancreas would preferentially utilize these substrates.

The mechanisms of time-dependent respiration deceleration in live cells are not known, and the possible causes are FCCP-induced changes in cytoplasmic $\mathrm{pH}, \mathrm{Ca}^{2+}$ and ATP level [15]. Cytosolic $\mathrm{pH}$ changes in response to protonophore could presumably occur due to equilibration with the extracellular solution and acidic compartments, but this should not depend on the oxidative substrate. In our study, FCCP (at least 0.5 and $1.5 \mu \mathrm{M}$ ) did not cause respiration deceleration when glutamine or dimethyl- $\alpha$-ketoglutarate was present. Thus, cytosolic $\mathrm{pH}$ seemingly does not play a major role in respiration deceleration. The deceleration was similar in cases of pyruvate and glucose oxidation. Thus, in time frames of the experiment, respiration decline seems not to depend on cytosolic ATP, which was shown to be maintained by glycolysis in case of oxidative phosphorylation deficit [9]. The deceleration 
A
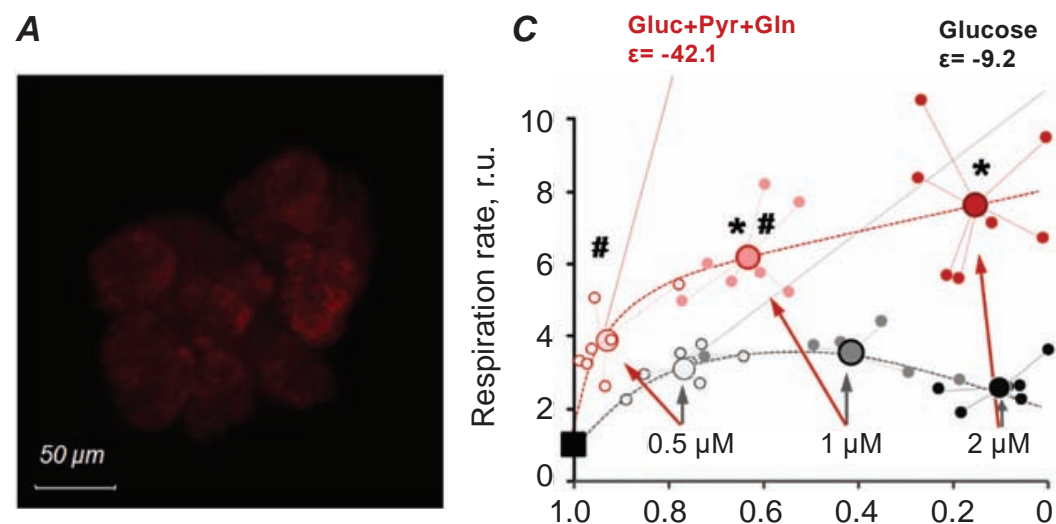

B

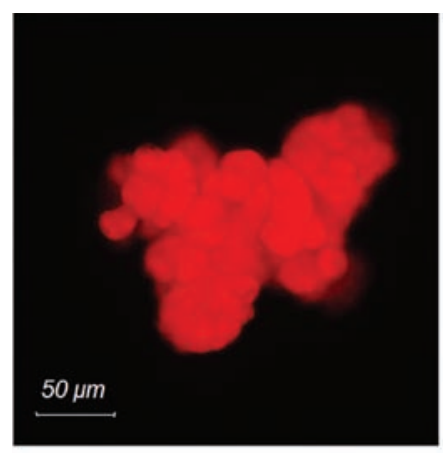

$D$

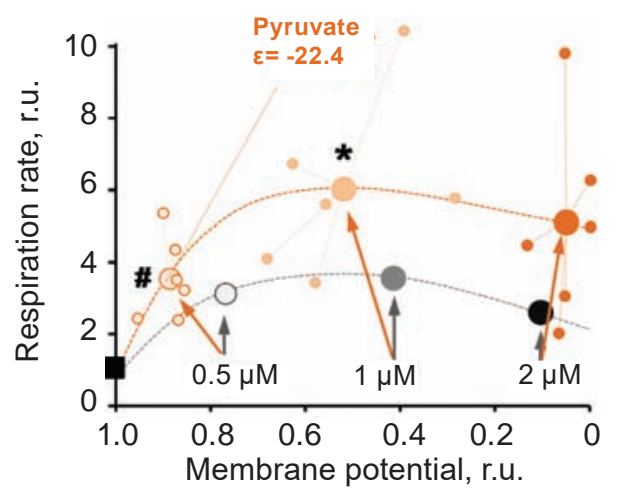

E

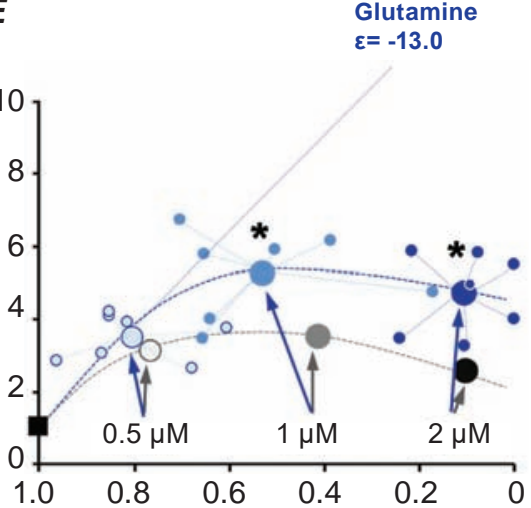

$\boldsymbol{F}$

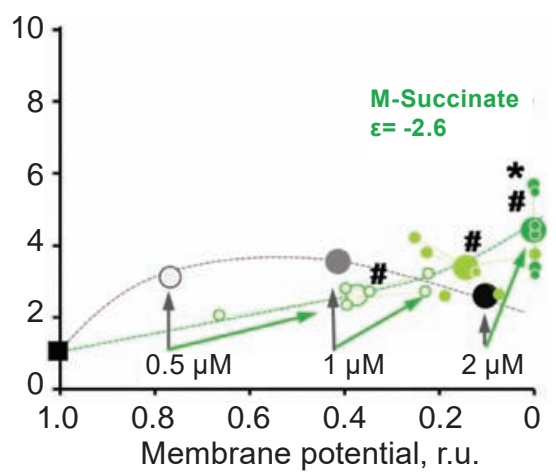

Fig. 4. Protonophore-induced mitochondrial membrane potential decrease and adaptive respiration stimulation of pancreatic acinar cells depends on oxidative substrate: rhodamine123-stained pancreatic acini before (A) and after 1 min of incubation with $2 \mu M F C C P(B)$, oxidative substrate - glucose (10 mM); $\boldsymbol{C}-\boldsymbol{F}$ - effects of substrates on the dependence of respiration rate on mitochondrial membrane potential; small markers values of each experiment, large markers - mean of 7 experiments; data normalized to basal values at 0 FCCP and $5 \mu \mathrm{M}$ oligomycin (black squares); FCCP concentration indicated on the plots in $\mu \mathrm{M}$, [glucose] $=10 \mathrm{mM}$, [pyruvate], [glutamine], [monomethyl-succinate] $=2 \mathrm{mM}$; significant changes of respiration rate $(*)$ or mitochondrial membrane potential (\#) comparing to glucose experiment (gray circles), $P<0.05 ; n=7$

was highest for substrates with apparently limited plasma membrane permeability (malate, isocitrate). Thus, insufficient substrate supply may be one of the causes of fast respiration decline.

The time-dependent decrease of uncoupled respiration is not limited to intact cell model, it was also evident in isolated pancreatic mitochondria upon succinate oxidation [6] and in isolated rat liver mitochondria, but only when $\alpha$-ketoglutarate was present $[17,18]$, not in case of other substrates. The involvement of substrate-level phosphorylation was assumed to be a mechanism of uncoupled respiration decline in isolated liver mitochondria [17]. It is clear that the mechanism is different in live pancreatic acinar cells, as FCCP does not cause deceleration of respiration upon both glutamine or dimethyl- $\alpha-$ ketoglutarate oxidation.
FCCP was shown to cause the opening of mitochondrial permeability transition pore in cardiomyocytes [19]. In the present study, we did not investigate the potential role of the pore in a timedependent decrease of uncoupled respiration.

Thus, we can conclude that time-dependent respiration deceleration and exacerbation of membrane potential dissipation is associated with the limited substrate transport and/or insufficient oxidation to match the uncoupled proton leak, albeit the precise mechanisms remain elusive.

In pancreatic acini, the "maximal” FCCP-uncoupled respiration rate, derived from a series of experiments with different protonophore concentrations, was different for each substrate or combination. For example, a combination of glucose with glutamine had a synergistic effect on the maximal 
uncoupled respiration, most likely because these substrates enter the Krebs cycle via different pathways. Thus, the maximal uncoupled respiration reflects the ability of cells to metabolize given substrates in response to protonophore loads rather than absolute maximal capacity of mitochondrial electron transport chain.

Optimal protonophore concentration seems to be an interesting integrative parameter, which is determined by the maximal uncoupled respiration and deceleration onset. It varies greatly with substrate composition. Thus, for each substrate composition, the new titration experiment should be conducted. In this study, the minimal tested FCCP concentration $(0.5 \mu \mathrm{M})$ ended up being the "optimal" for a number of substrates, but in reality, it is probably much lower.

Interestingly, the optimal FCCP concentration was different for three related substrates, glutamine, glutamate and dimethyl- $\alpha$-ketoglutarate. Glutamate was less able to sustain uncoupled respiration of pancreatic acinar cells then glutamine or dimethyl$\alpha$-ketoglutarate. In rat and murine pancreatic acinar cells, glutamate transporters expression is lower than neutral amino acids transporters [20, 21]. Moreover, glutamate is secreted into pancreatic juice by pancreata of rats [20], presumably due to predominantly apical localization of EAAC1 glutamate transporter. Thus we assume that unsustained respiratory response to FCCP upon glutamate oxidation was due to its limited transport across the basal plasma membrane. This hypothesis is further supported by the fact that the uncoupled respiration was stimulated by membrane-permeant dimethyl- $\alpha$-ketoglutarate, and not by $\alpha$-ketoglutarate, a metabolite of glutamate.

The dependence of respiration on mitochondrial membrane potential in most cases seems to be consistent with the established kinetic models [22], and the elasticity coefficients are similar to those obtained on isolated mitochondria [23]. However, when monomethyl-succinate was oxidized, the elasticity coefficient was very low, i.e. respiratory response was "delayed" and substantially increased only when the membrane potential had completely dissipated. We assume that mitochondrial complex I is much more sensitive to membrane depolarization than complex II in pancreatic acinar cells.

Importantly, the optimal substrate combination was able not only to elicit the maximal respiratory response to FCCP, but also reduce the protonophorecaused depolarization. It is known that glutamine supplementation [24] improves outcomes of patients with acute pancreatitis, and pyruvate protects pancreatic acinar cells in vitro from apoptosis and necrosis [25]. In principle, pyruvate and glutamine might protect pancreatic acinar cells from damage by ameliorating the mitochondrial depolarization in the course of pancreatitis pathogenesis.

In conclusion, the combination of glutamine, pyruvate and glucose maintains a high respiration rate and provides the most reducing equivalents to the respiratory chain to support the highest membrane potential levels upon the protonophore loads. Further research of the mitochondrial substrate metabolism in pancreas might lead to the discovery of new therapeutic options for patients with pancreatitis.

Acknowledgements. Authors express their deep gratitude to the company "Material Phases Data System" for the financial support of the study and to Andriy Babsky, D.Sc. for the article proofreading.

Conflict of interest. Authors have completed the Unified Conflicts of Interest form at http:// ukrbiochemjournal.org/wp-content/uploads/2018/12/ coi_disclosure.pdf and declare no conflict of interest.

\section{АДАПТАЦІЙНА ВІДПОВІДЬ АЦИНАРНИХ КЛІТИН ПІДШЛУНКОВОЇ ЗАЛОЗИ ЩУРІВ НА ДЕПОЛЯРИЗАЦЮЮ ВНУТРІШНЬОЇ МЕМБРАНИ МІТОХОНДРІЙ}

\author{
Б. О. Манько \\ Львівський національний університет \\ імені Івана Франка, Україна; \\ 凶e-mail: bohdan.manko@lnu.edu.ua
}

Залежність роз'єднаного дихання інтактних панкреатичних ацинусів від субстратів окислення та функціонального стану клітини не досліджено. У роботі реєстрували базальну швидкість та швидкість FCCР-стимульованого дихання ізольованих панкреатичних ацинусів за допомогою електрода Кларка і оцінювали мембранний потенціал мітохондрій за інтенсивністю флуоресценції родаміну 123 . Відповідь ацинусів на внесення FCCP характеризували максимальною швидкістю роз'єднаного дихання, оптимальною концентрацією FCCP, прискоренням та спо- 
вільненням дихання. Максимальна швидкість роз'єднаного дихання істотно збільшилася за окислення глюкози + глутаміну $(3,03 \pm 0,54$ в.о.), глюкози + глутаміну + пірувату $(2,82 \pm 0,51$ в.о.), глюкоза + ізоцитрат $(2,71 \pm 0,33$ в.о.), глюкози + малату $(2,75 \pm 0,38$ в.о.), глюкози + монометилсукцинату $(2,64 \pm 0,42$ в.о.) або глюкози + диметил$\alpha$-кетоглутарату $(2,36 \pm 0,33$ в.о.) у порівнянні 3 максимальною швидкістю роз'єднаного дихання за окислення лише глюкози (1,73-2,02 в.о.) або за відсутності екзогенних субстратів окислення $(1,76 \pm 0,33$ в.о.). Оптимальна концентрація FCCP виявилася найвищою (1,75 мкM) за окислення суміші глюкози + глутаміну + пірувату та найнижчою $(0,5$ мкM) - за окислення екзогенного глутамату або суміші глюкози 3 такими субстратами, як ізоцитрат, малат, сукцинат або $\alpha$-кетоглутарат. Прискорення дихання після додавання FCCP було найвищим за окислення диметил- $\alpha$-кетоглутарату. Після досягання піка швидкості дихання ацинарними клітинами підшлункової залози у багатьох експериментах спостерігалось часозалежне сповільнення швидкості дихання. Це сповільнення дихання збільшувалося за збільшення концентрації FCCP і залежало від субстрату окислення. Найістотнішим воно було за окислення малату та ізоцитрату. Піруват сам по собі чи його комбінація з глутаміном та глюкозою значно знижували деполяризацію внутрішньої мембрани мітохондрій, спричинену дією FCCP, а також підвищували коефіцієнт еластичності залежності дихання від зміни мембранного потенціалу. Отже, суміш пірувату, глутаміну та глюкози є оптимальною для підтримання адаптивної здатності мітохондрій панкреатичних ацинусів відповідати на деполяризацію їхньої внутрішньої мембрани.

К л ю чов і с лов а: панкреатичні ацинуси, споживання кисню, мітохондрії, деполяризація, роз'єднувачі дихання, субстрати окислення.

\section{References}

1. Kosowski H, Schild L, Kunz D, Halangk W. Energy metabolism in rat pancreatic acinar cells during anoxia and reoxygenation. Biochim Biophys Acta. 1998; 1367(1-3): 118-126.

2. Schulz HU, Pross M, Meyer F, Matthias R, Halangk W. Acinar cell respiration in experimental acute pancreatitis. Shock. 1995; 3(3): 184-188.

3. Shalbueva N, Mareninova OA, Gerloff A, Yuan J, Waldron RT, Pandol SJ, Gukovskaya AS. Effects of oxidative alcohol metabolism on the mitochondrial permeability transition pore and necrosis in a mouse model of alcoholic pancreatitis. Gastroenterology. 2013; 144(2): 437-446.e6.

4. Huang W, Booth DM, Cane MC, Chvanov M, Javed MA, Elliott VL, Armstrong JA, Dingsdale H, Cash N, Li Y, Greenhalf W, Mukherjee R, Kaphalia BS, Jaffar M, Petersen OH, Tepikin AV, Sutton R, Criddle DN. Fatty acid ethyl ester synthase inhibition ameliorates ethanol-induced $\mathrm{Ca}^{2+}$ dependent mitochondrial dysfunction and acute pancreatitis. Gut. 2014; 63(8): 1313-1324.

5. Voronina SG, Barrow SL, Gerasimenko OV, Petersen OH, Tepikin AV. Effects of secretagogues and bile acids on mitochondrial membrane potential of pancreatic acinar cells: comparison of different modes of evaluating DeltaPsim. J Biol Chem. 2004; 279(26): 2732727338.

6. Mukherjee R, Mareninova OA, Odinokova IV, Huang W, Murphy J, Chvanov M, Javed MA, Wen L, Booth DM, Cane MC, Awais M, Gavillet B, Pruss RM, Schaller S, Molkentin JD, Tepikin AV, Petersen OH, Pandol SJ, Gukovsky I, Criddle DN, Gukovskaya AS, Sutton R. Mechanism of mitochondrial permeability transition pore induction and damage in the pancreas: inhibition prevents acute pancreatitis by protecting production of ATP. Gut. 2016; 65(8): 1333-1346. 
7. Mankad P, James A, Siriwardena AK, Elliott AC, Bruce JI. Insulin protects pancreatic acinar cells from cytosolic calcium overload and inhibition of plasma membrane calcium pump. $J$ Biol Chem. 2012; 287(3): 1823-1836.

8. Schild L, Matthias R, Stanarius A, Wolf G, Augustin W, Halangk W. Induction of permeability transition in pancreatic mitochondria by cerulein in rats. Mol Cell Biochem. 1999; 195(1-2): 191-197.

9. Voronina SG, Barrow SL, Simpson AW, Gerasimenko OV, da Silva Xavier G, Rutter GA, Petersen $\mathrm{OH}$, Tepikin AV. Dynamic changes in cytosolic and mitochondrial ATP levels in pancreatic acinar cells. Gastroenterology. 2010; 138(5): 1976-1987.

10. Manko BO, Manko VV. Mechanisms of respiration intensification of rat pancreatic acini upon carbachol-induced $\mathrm{Ca}(2+)$ release. Acta Physiol (Oxf). 2013; 208(4): 387-399.

11. Odinokova IV, Sung KF, Mareninova OA, Hermann K, Evtodienko Y, Andreyev A, Gukovsky I, Gukovskaya AS. Mechanisms regulating cytochrome c release in pancreatic mitochondria. Gut. 2009; 58(3): 431-442.

12. Choi SW, Gerencser AA, Nicholls DG. Bioenergetic analysis of isolated cerebrocortical nerve terminals on a microgram scale: spare respiratory capacity and stochastic mitochondrial failure. J Neurochem. 2009; 109(4): 1179-1191.

13. Dranka BP, Benavides GA, Diers AR, Giordano S, Zelickson BR, Reily C, Zou L, Chatham JC, Hill BG, Zhang J, Landar A, Darley-Usmar VM. Assessing bioenergetic function in response to oxidative stress by metabolic profiling. Free Radic Biol Med. 2011; 51(9): 1621-1635.

14. Doliba NM, Qin W, Vatamaniuk MZ, Buettger CW, Collins HW, Magnuson MA, Kaestner KH, Wilson DF, Carr RD, Matschinsky FM. Cholinergic regulation of fuel-induced hormone secretion and respiration of SUR1 ${ }^{-/}$mouse islets. Am J Physiol Endocrinol Metab. 2006; 291(3): E525-E535.

15. Brand MD, Nicholls DG. Assessing mitochondrial dysfunction in cells. Biochem J. 2011; 435(2): 297-312.
16. Manko BO, Klevets MY, Manko VV. An implication of novel methodology to study pancreatic acinar mitochondria under in situ conditions. Cell Biochem Funct. 2013; 31(2): 115-121.

17. Olson MS, Allgyer TT. The inhibition of L(--)palmitylcarnitine oxidation by -ketoglutarate in rat liver mitochondria. Biochim Biophys Acta. 1972; 267(2): 238-248.

18. Kondrashova MN1, Doliba NM. Polarographic observation of substrate-level phosphorylation and its stimulation by acetylcholine. FEBS Lett. 1989; 243(2): 153-155.

19. Gordan R, Fefelova N, Gwathmey JK, Xie LH. Involvement of mitochondrial permeability transition pore (mPTP) in cardiac arrhythmias: Evidence from cyclophilin D knockout mice. Cell Calcium. 2016; 60(6): 363-372.

20. Fukushima D, Doi H, Fukushima K, Katsura K, Ogawa N, Sekiguchi S, Fujimori K, Sato A, Satomi S, Ishida K, Fukushima K. Glutamate exocrine dynamics augmented by plasma glutamine and the distribution of amino acid transporters of the rat pancreas. $J$ Physiol Pharmacol. 2010; 61(3): 265-271.

21. Rooman I, Lutz C, Pinho AV, Huggel K, Reding T, Lahoutte T, Verrey F, Graf R, Camargo SM. Amino acid transporters expression in acinar cells is changed during acute pancreatitis. Pancreatology. 2013; 13(5): 475-485.

22. Jin Q, Bethke CM. Kinetics of electron transfer through the respiratory chain. Biophys J. 2002; 83(4): 1797-1808.

23. Brand MD, Hafner RP, Brown GC. Control of respiration in non-phosphorylating mitochondria is shared between the proton leak and the respiratory chain. Biochem J. 1988; 255(2): 535539.

24. Zhong X, Liang CP, Gong S. Intravenous glutamine for severe acute pancreatitis: A metaanalysis. World J Crit Care Med. 2013; 2(1): 4-8.

25. Huang W, Xiong JJ, Cheng CR, Szatmary P, Chvanov M, Criddle DN, Xia Q, Sutton R. Therapeutic potential of pyruvate in acute pancreatitis: In Vitro findings and a systematic review. Pancreatology. 2016; 16(1): S32. 